\title{
CORRECTION
}

\section{Correction to: Development as education for social justice}

\author{
Sung-Sang Yoo ${ }^{1} \cdot$ Ridwanul Mosrur $^{1} \cdot$ Eunhye Lee $^{1} \cdot$ Diego Andres Toca Bermeo $^{1}$
}

Published online: 17 May 2020

(c) Education Research Institute, Seoul National University, Seoul,Korea 2020

\section{Correction to:}

Asia Pacific Education Review (2019) 20:259-27

https://doi.org/10.1007/s12564-019-09603-2

In the original publication of the article the fourth author name, Diego Andres Toca Bermeo was misspelled. The correct name is given in this Correction.

Publisher's Note Springer Nature remains neutral with regard to jurisdictional claims in published maps and institutional affiliations. 